\title{
Antagonism Potential of Trichoderma viride against Erysiphe necator in the Culture of Grapevine under Field Conditions
}

\author{
Hanna Cáceres Yparraguirre ${ }^{1^{*}}$, Juan José Siguas-Guerrero ${ }^{1}$, Vladimir Prado-Flores ${ }^{1}$, Claudia Luciana \\ Galliani-Pinillos ${ }^{1}$ and Soria Juan $\mathrm{J}^{2}$ \\ ${ }^{1}$ Center for Agroindustrial Technological Innovation, Panamericana Sur Km 293.3 Salas Guadalupe Ica, CITE-Agroindustrial, Ica, \\ Peru; ${ }^{2}$ Private Statistical Advisor, Peru
}

\begin{abstract}
The vine is a crop affected by various pests and diseases. Being the oidium produced by Erysiphe necator one of the most important. Generally the farmer, due to lack of knowledge makes an inappropriate use of fungicides, which is harmful, since the intensive use (and sometimes excessive) of chemical products has had negative effects on the environment and the quality of life of human populations. That is why the present investigation set out to develop a clean technology with the use of antagonistic fungi Trichoderma viride for the control of E. necator in the Italian vine variety in field conditions. Two treatments were performed in parallel. The first consisted of the exclusive use of $T$. viride, and the second of the exclusive use of chemical products. Sanitary applications were given once a week, from the phenological stage of inflorescence until berry ripening. By the other hand the chemical treatment consisted of five applications with fungicides of different active ingredients. The variables evaluated were incidence and severity of oidium in leaves and clusters. The treatment with exclusive use of T. viride presented an average efficiency of $92 \%$ in the leaves and $81 \%$ in clusters. This data is very useful for farmers, since the possibility of using a biological controller as another less invasive and harmful alternative in the control of E. necator. Therefore, T. viride can be a good strategy if it is applicator in the first phenological stages. So to ensure its functioning, a correct application dose, good maintenance of the backpack sprayer, and proper handling of the canopy must be taken into account. Also is suggested to extend the study using native Trichoderma strains as well as to implement other beneficial microorganisms.
\end{abstract}

Keywords: Biological control; Trichoderma viride; Biofungicide; Erysiphe necator; Vitis vinifera cv Italia

\section{INTRODUCTION}

The cultivation of grapevine in Peru is one of the most important; table grapes, grapes for Pisco and grapes for wine are grown. The varieties called Pisco grapes are eight (Quebranta, Negra criolla, Uvina, Mollar, Albilla, Italia, Torontel and Moscatel), of which Pisco is made, a grape liquor, colorless, considered as the flagship drink of Peru. Its designation of origin covers the Departments of Lima, Ica, Arequipa, Moquegua and Tacna [1].

The story tells that the epicenter and where viticulture is widely established is the Ica Valley, where the city of Valverde was founded in 1563 [2] and continues to enjoy that characteristic by occupying $55 \%$ of the national production of grapes used in Pisco and the first place in the production of table grapes and wine grapes [3]. Various pests (insects and diseases) have the grapevine as a host and the vineyard as a preferred environment. Therefore, an intensive pesticide program is generally required to meet agricultural production standards [4]. In general, fungicides represent the majority of pesticide treatments in most vineyards (12 to 15 applications are usually required, up to 25 to 30 applications in the most problematic conditions) [4].

Erisyphe necator is a fungus that causes powdery mildew of grapevines, also called oidium in Peru, which causes a significant

*Correspondence to: Hanna Cáceres Yparraguirre, Agricultural Area of the Center for Agroindustrial Technological Innovation, Panamericana Sur Km 293.3 Salas Guadalupe Ica, CITE-Agroindustrial Ica, Peru, Tel: +51956185178; E-mail: hcaceres@citeagroindustrial.com

Received date: December 24, 2019; Accepted date: March 10, 2020; Published date: March 17, 2020

Citation: Yparraguirre HC, Siguas-Guerrero JJ, Prado-Flores V, Galliani-Pinillos CL, Soria-Juan J (2020) Antagonism Potential of Trichoderma viride against Erysiphe necator in the Culture of Grapevine under Field Conditions. Plant Pathol Microbiol. 11:489. doi: 10.35248/2157-7471.20.11.489.

Copyright: (C) 2020 Yparraguirre HC, et al. This is an open-access article distributed under the terms of the Creative Commons Attribution License, which permits unrestricted use, distribution, and reproduction in any medium, provided the original author and source are credited. 
loss in the quantity and quality of yield [5], reducing the productivity, sometimes from $20 \%$ to $40 \%$ [6]. The symptoms of oidium occur by attacking the young organs of the grapevine, leaves, buds, branches, inflorescences and fruits, manifesting in the form of white spots, which are covered with a whitish and powdery layer; that at the end of the activity of the plant changes to dark-brown or brown [7], rarely kill their hosts, however, they use their nutrients, decrease their photosynthesis, increase their breathing and perspiration [6]

Oidium persists as mycelium, associated with infected buds of the previous season, and as cleistotecios that develop in leaves and other aerial organs of the grapevine. In rainy areas it is possible that the ascospores constitute the main source of primary inoculum, while the mycelium associated with infected buds, apparently, and is the main source of primary inoculum in extremely dry areas. The susceptibility of grapevine clusters varies throughout the growing season, being very susceptible between the phenological stages of setting and ripening. The risk of infection depends on the pressure of oidium in the vineyard, which is directly related to ambient temperature and humidity [8].

For the control of oidium, a series of fungicides have been used, which are widely used inputs in agriculture, which results in a high cost for producers and cause serious health problems in humans, such as causing cancer or carrying consequences for the reproductive, immune or nervous systems [9]. In addition, they can produce drastic effects on the environment; for example, water pollution, which is a vector so that other animals can drink and, therefore, cause them intoxication and subsequently death. High winds can blow chemicals away from diseased crops to other non-diseased areas. Also, the use of fungicides can select populations of resistant pests. New tools based on biological control agents could be promising strategies that are used alone or in combination with reduced doses of chemicals [10].

Biological control through the use of biopesticides is a viable and sustainable alternative for the control of pests in agricultural crops. These bioproducts do not leave toxic residues and are usually specific to their biological target, reducing the risk of resistance selection in pests $[11,12]$. In several countries (United States, member countries of the European Union and Latin America, with the exception of Ecuador, Haiti, Panama and the Dominican Republic) the legislation is favoring greater development and use of biopesticides, over chemical pesticides $[13,14]$.

Among the microorganisms most used in biological control are fungi of the genus Trichoderma, which are subject to research and development in many countries [15-20]. Trichoderma spp. is ubiquitous colonizers of cellulosic materials and, therefore, can often be found as long as decomposing plant material is available [21]. They live in the soil and rhizosphere, and function as parasites of other fungi. They are also used as biopesticides and biofertilizers [10], because they have shown influence in the promotion of vegetative growth and also induce immunity against phytopathogens in the plants with which they are associated [22]. The importance of Trichoderma spp. is recognized for its mycoparasitic and antagonistic effect associated with the production of lytic enzymes; the production of antibiotics with antifungal characteristics, bioherbicides such as viridiol. Likewise, this microorganism is a good producer of xylanases, $\beta$-glucanases that are industrially synthesized to carry out the process and finishing of denim fabrics [23].

Two investigations evaluated the biocontrol with Trichoderma spp. at field level. In Egypt, the microorganisms $T$. viride, $T$. harzianum and T. hamatum were used for the control of E. necator in the Thompson Seedless grapevine variety, where bioagents reduced disease parameters, reporting $80.2 \%$ and $89.9 \%$ efficacy in reducing disease incidence and severity, respectively, in two trial campaigns during 2016 and 2017 [5]. On the other hand, in Chile, the biocontroller effectiveness of Bacillus subtilis (Nacillus) and two native strains of Trichoderma spp. (Trichonativa) on the incidence and severity of oidium in Vitis vinifera variety Cabernet Sauvignon was evaluated. The results of that study showed that Trichonativa products, Nacillus, and the mixture of both, showed a significant reduction of the disease. The treatments with the mixture of the products (Trichonativa + Nacillus) and only Nacillus, applied in three susceptible stages of the grapevine, presented the best results, obtaining an incidence of the disease (37.0\% and $45.2 \%$, respectively) significantly lower $(\mathrm{P}<0.001)$ than that presented by the control untreated clusters [24].

The objective of this study was to evaluate the antagonistic capacity of Trichoderma viride against the phytopathogen Erysiphe necator in the cultivation of grapevine variety Italia under field conditions. The efficacy of biological control with $T$. viride versus conventional treatment with chemical fungicides was compared.

\section{MATERIALS AND METHODS}

\section{Study area}

The present investigation was carried out in the district of Humay $\left(13^{\circ} 43^{\circ} 06.8^{\circ} \mathrm{S}\right.$; $75^{\circ} 52^{\prime} 47.1^{\prime \prime} \mathrm{W}$; altitude 430 meters above sea level), Province of Pisco, Department of Ica, vineyard producing area for Pisco and table grapes. Located on the south coast of Peru. Its climate in summer is typically arid and cloudy, and in winter it is dry and clear. During the course of the year, the temperature generally varies from $15^{\circ} \mathrm{C}$ to $27^{\circ} \mathrm{C}$; It rarely drops below $12^{\circ} \mathrm{C}$ or rises above $30^{\circ} \mathrm{C}$. In Humay, the frequency of wet days (those with more than 1 millimeter of liquid precipitation or liquid equivalent precipitation) does not vary considerably according to the season (range between $0 \%$ to $3 \%$, average value: $1 \%$ ) (Figure 1 ).

\section{Vegetal material}

The research work on the cultivation of grapevine, $V$. vinifera, variety Italia was carried out during the entire agricultural campaign of 2018, from the phenological stage of inflorescence to ripening berries.

The vineyard where the research was conducted is a commercial vineyard that had 43 plantation lines, where each line had 50 plants. The owner assigned two plantation lines to apply biological products, which were arranged in the last lines of the vineyard, that is line 42 and line 43 , correctly marked with a 
sign because there was no separation between the two groups, giving strict instructions to the field manager and to the operator so that the chemical phytosanitary control is not applied. The 41 planting lines rest were subjected to the application of chemical products (Figure 2). The age of the plants was 2 years and they were grafted with a R99 pattern. The plants were driven under the double $\mathrm{T}$ conduction system and managed under drip irrigation. The soil was clay loam type. The grapevines were pruned at the end of August.

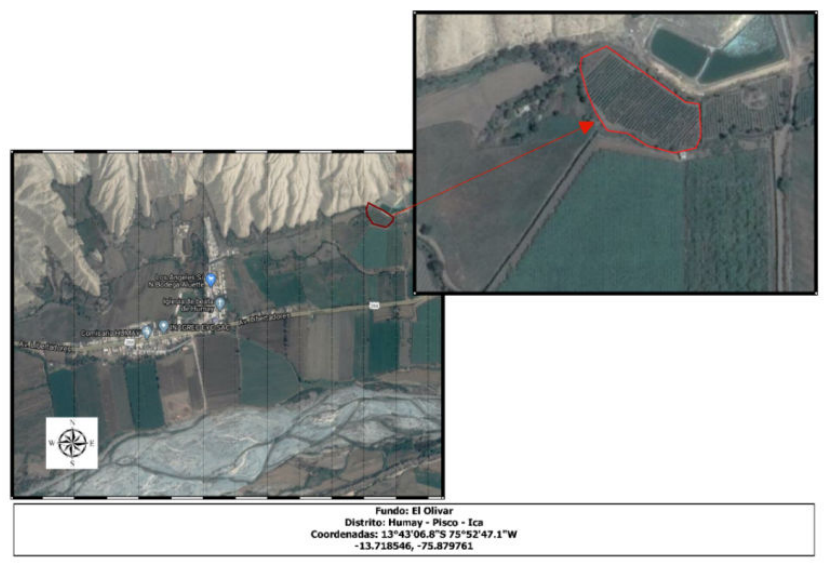

Figure 1: Study area: Department of Ica, province of Pisco, District Humay.

\begin{tabular}{|c|c|c|c|c|c|c|c|c|}
\hline L1 & P1 & P2 & P3 & P4 & P5 & $\ldots$ & P50 & \multirow{6}{*}{$\begin{array}{l}\text { Chemica } \\
\text { treatmen }\end{array}$} \\
\hline L2 & P1 & P2 & P3 & P4 & P5 & $\ldots$ & P50 & \\
\hline & & & & & & & & \\
\hline & & & & & & & & \\
\hline & & & & & & & & \\
\hline$\llcorner 41$ & P1 & $\mathrm{P} 2$ & P3 & P4 & P5 & $\ldots$ & P50 & \\
\hline$\angle 42$ & P1 & P2 & P3 & P4 & P5 & $\ldots$ & P50 & \multirow{2}{*}{$\begin{array}{l}\text { Biological } \\
\text { treatmen }\end{array}$} \\
\hline L43 & P1 & P2 & P3 & P4 & P5 & $\ldots$ & P50 & \\
\hline
\end{tabular}

Figure 2: Design of the experimental field.

\section{Preparation of the biological control agent in the field}

The commercial product PBA (bags per $800 \mathrm{~g}$ in rice substrate) based on Trichoderma viride strain CCBLA103 [25] was used, which was obtained by the UVASANA project in 2017-2018 subsidized by the National Agrarian Innovation Program (PNIA) of the National Institute of Agrarian Innovation (INIA).

Each week before applying the biological product, in order to verify the quality of the product, the researchers made a count of conidia of $T$. viride, reporting a concentration of $4 \times 10^{7}$ conidia/g. This differed from the initial concentration of the commercial product $\left(1.5 \times 10^{10}\right.$ conidia/g $)$ and the minimum dose $\left(4.5 \times 10^{9}\right.$ conidia/g) recommended by the National Agricultural Health Service (SENASA) [25].

For the preparation of the biological product, water (which varied between 0.25 to $1 \mathrm{~L}$ per plant, according to its phenological stage) was added in a plastic bucket, then the $\mathrm{pH}$ $(5.5-6.5)$ and the diluent hardness were corrected adding an adherent, acidifying, $\mathrm{pH}$ indicator, softener, compatibility agent based on alkyl aryl polyethoxy ethanol 14\%, additives and inert $86 \%$. To the $800 \mathrm{~g}$ bags of rice containing T. viride, $40 \mathrm{~mL}$ of agricultural oil was added to encapsulate the spores; the mixture was stirred and added to the bucket with water. The liquid was taken to the backpack sprayer for its application and the rice residues were scattered on foot from some plants of the live fence.

\section{Application of the treatments in the field}

The application of the treatments was by foliar route using a backpack sprayer with an adjustable nozzle of $1.6 \mathrm{l} / \mathrm{min}$. It was performed at 16 hours to ensure that the temperature did not affect the colonization and mycoparasitism of the antagonist, and that the conidia were not affected by the sun's radiation.

Two treatments were performed in parallel. The first consisted of the exclusive use of T. viride, and the second of the exclusive use of chemical products. Sanitary applications with $T$. viride were given once a week, from the phenological stage of inflorescence until berry ripening. The chemical treatment consisted of five applications with fungicides of different active ingredients (mancozeb + metalaxyl, penconazole, fosetyl aluminium, spiroxamine, pyrimethanil), according to the recommendations of the professional advisor hired by the farmer.

\section{Plant parameters adopted to evaluate treatments}

Every 7 days after the last application, evaluations of ten plants were made selected by a simple random sampling, making a total of 80 leaves and 60 clusters, both for the chemical and biological treatments. In our investigation they were not considered control plants, because the variety Italia is very susceptible to the attack of the fungus E. necator. That is why it was decided to take the chemical method as a control treatment, as a way to compare it with the biological treatment, considered it experimental treatment. The commercial strain of $T$. viride was used exclusively at a real concentration of $4 \times 10^{7}$ conidia/g, which did not exert $100 \%$. The variables evaluated were incidence and severity of oidium.

The incidence of oidium (I, in percentage) was determined according to the formula

$$
\mathrm{I} \%=\frac{\text { Number of infected leaves } / \text { bunches }}{\text { Total of leaves } / \text { bunches evaluated }} \times 100
$$

The severity of the disease was recorded before the application of biological treatments, that is, every 7 days. It was classified on a scale of 0 to 5 , where: $0=$ no infection; $1=1-10 \%$ of leaf area infected with powdery mildew fungi or oidium; $2=11-25 \% ; 3=$ $26-50 \% ; 4=51-75 \%$ and $5=76-100 \%$ [26] (Figure 3). The scores became a disease severity index (D.S.I.), using the formula given by Wheeler [27]:

D.S.I\% $=\frac{(\mathrm{n} . \mathrm{v})}{\mathrm{ZN}} \times 100$ Where $\mathrm{n}=$ Number of leaves/bunches in each scale, =Numerical value of each scale, $Z=$ Numerical value of the highest scale, and $\mathrm{N}=$ Total of leaves/bunches in the sample. 

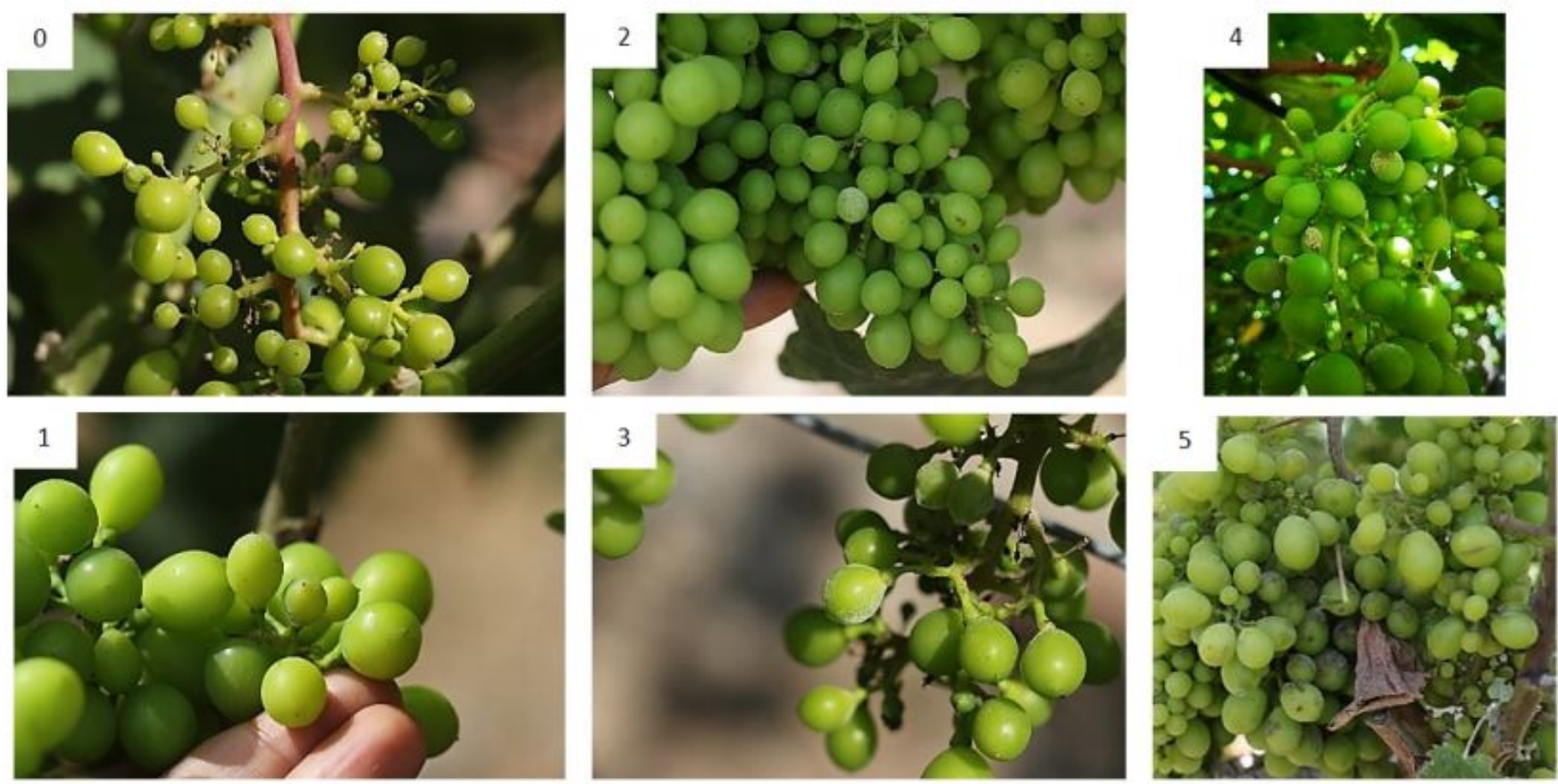

Figure 3: Bunch infested with oidium in category $0-1-2-3-4$ in the Province of Pisco, Humay.

\section{Statistical analysis}

The data obtained for the two variables evaluated (incidence and severity of oidium) were expressed as a percentage and the angular transformation of Bliss was performed. Then the data underwent the Kolmogorov - Smirnov test of normality, where $\mathrm{P}<0.01$ was obtained with the two variables (the data did not follow a normal distribution). Therefore, the non-parametric Wilcoxon test was used for independent samples, with a significance level of 0.05 . The InfoStat software version 2018 was used.

\section{RESULTS AND DISCUSSION}

\section{Incidence and severity of oidium}

The results of the determination of the percentage incidence of oidium in leaves and clusters during the five phenological stages of $V$. vinifera by treatment showed that there was a statistically significant difference between the biological and chemical treatment, in leaves and clusters (Tables 1 and 2). Regarding $T$. viride, it was observed that at the beginning of the investigation in leaves, the incidence of oidium began with $2.14 \%$. However, this tended to increase when the grapevine cultivation passed through other phenological stages, reaching up to $24.51 \%$ in the phenological stage of berry ripening. On the other hand, better control of oidium was observed in the chemical applications. Although the incidence of oidium in leaves at the beginning of the investigation was higher under the chemical treatment (12.64\%) compared to the biological treatment (2.14\%), with the advance of the phenology, the incidence of oidium under the chemical treatment tended to decrease in flowering, berries peasize and berry ripening (reaching $6.95 \%$ in the latter). Here we notice the difference with the use of fungicides, because they attack directly on the fungus, slowing its development by presenting a protective and healing action. The grapevine variety Italia is susceptible to the oidium. In the clusters a lower control of oidium was obtained in the treatment with $T$. viride presenting an incidence of $2.47 \%$ to $54.86 \%$, unlike the treatment with chemicals whose maximum value was $26.50 \%$ in berry ripening.

The evaluation of the severity of oidium (Tables 3 and 4) revealed an increase in the severity of the disease with the progression of the phenological stages, that is, when the leaves were evaluated in the phenological stages of bunch closure and berry ripening, $T$. viride had the lowest effectiveness, presenting severity indices of $12.33 \%$ and $14.76 \%$ in leaves, respectively (Table 3); and in clusters from $38.98 \%$ to $28.20 \%$ in the same phenological stages, respectively (Table 4). This is probably due to the fact that the experimental lines were located at the edges of the plot, so they would be more susceptible to being attacked by this fungus. In these two phenological stages (bunch closure and berry ripening) the oidium is more aggressive in clusters than in leaves. This is because the fungus has a preference for tender tissue, and at that time the cessation of leaf growth occurs and the transport of nutrients goes to the growing clusters. The phytopathogen attacks the green berries of the cluster.

Table 1: Incidence of oidium (\%) in leaves in five phenological stages of Vitis vinifera by treatment.

\begin{tabular}{llll}
\hline Phenological stages & \multicolumn{2}{l}{ Treatment } & Sig. (P) \\
\cline { 2 - 4 } & T. viride & Chemical & \\
\hline Inflorescence emerge & 2.14 & 12.64 & 0.0001
\end{tabular}




\begin{tabular}{lccc}
\hline Flowering & 9.79 & 11.06 & 0.0012 \\
\hline Berries pea-size & 10.79 & 9.34 & 0.0922 \\
\hline Bunch closure & 21.53 & 9.10 & 0.0001 \\
\hline Ripening of berries & 24.51 & 6.95 & 0.0001 \\
\hline
\end{tabular}

Table 2: Incidence of oidium (\%) in bunches in five phenological stages of Vitis vinifera by treatment.

\begin{tabular}{llll}
\hline Phenological stages & \multicolumn{2}{c}{ Treatment } & Sig. (P) \\
\cline { 2 - 4 } & T. viride & Chemical \\
\hline Inflorescence emerge & 2.47 & 0.00 & 0.0006 \\
\hline Flowering & 21.35 & 4.95 & 0.0001 \\
\hline Berries pea-size & 22.77 & 11.94 & 0.0001 \\
\hline Bunch closure & 54.86 & 10.12 & 0.0156 \\
\hline Ripening of berries & 47.78 & 26.50 & 0.0001 \\
\hline
\end{tabular}

Table 3: Severity index (\%) of oidium in leaves in five phenological stages of Vitis vinifera by treatment.

\begin{tabular}{llll}
\hline Phenological stages & \multicolumn{2}{c}{ Treatment } & \multicolumn{2}{c}{ Sig. (P) } \\
\cline { 2 - 4 } & T. viride & Chemical \\
\hline Inflorescence emerge & 1.06 & 1.06 & 0.9999 \\
\hline Flowering & 4.89 & 5.28 & 0.0012 \\
\hline Berries pea-size & 5.54 & 5.54 & 0.9999 \\
\hline Bunch closure & 12.33 & 5.83 & 0.0001 \\
\hline Ripening of berries & 14.76 & 4.20 & 0.0001 \\
\hline
\end{tabular}

Table 4: Severity index (\%) of oidium in bunches in five phenological stages of Vitis vinifera by treatment.

\begin{tabular}{llll}
\hline Phenological stages & \multicolumn{2}{c}{ Treatment } & Sig. (P) \\
\cline { 2 - 4 } & T. viride & Chemical \\
\hline Inflorescence emerge & 1.24 & 1.24 & 0.9999 \\
\hline Flowering & 10.49 & 10.49 & 0.9999 \\
\hline Berries pea-size & 12.89 & 12.89 & 0.9999 \\
\hline Bunch closure & 38.98 & 21.38 & 0.0001 \\
\hline Ripening of berries & 28.20 & 13.97 & 0.0001 \\
\hline
\end{tabular}

Of the five phenological stages evaluated, in the bunch closure and berry ripening is where a lower control of oidium was

observed using treatment with $T$. viride when evaluating leaves and clusters. This may be because the leaves are organs that remain green all the time; therefore, they are very attacked by the pest, as indicated by Fernández [28]. In addition, at the time of post-harvest the oidium does not die but remains dormant in the crop until waiting for a next regrowth of the plant, as indicated by several studies [29-32]. Therefore, the fungus can affect all succulent tissues of the grapevine, including leaves, stems, fruits and inflorescence, which acquire characteristic symptoms [31,32]. The susceptibility of these organs differs according to the variety.

Oidium disease cannot be cured but treated. Therefore, it is recommended to apply biological products in a preventive way to avoid the exposure of grapevine cultivars to E. necator infection. There are multiple factors that may have helped the proliferation of the phytopathogen, such as temperature, humidity, as well as an inadequate cultural control. The latter is very important, because the selection of an open site, the orientation of the rows so that air circulation is favored, and the search for the sun's rays to penetrate directly throughout the grapevine plant can not only decrease the incidence and severity of the disease, but also help increase the coverage of the compounds that are sprayed to control this fungus [33].

The oidium can be devastating in susceptible grapevine varieties such as the Italia variety. It develops in conditions of high humidity, but not by free water [34], that is, the fungus does not need free water on the surface of green tissue for infection to occur. It only requires that the relative humidity of the air be high for the germination of the spores to occur [35].

It should be taken into account that the release of ascospores has always been associated with rainy periods where cumulative rainfall ranged between 2.0 and $58.5 \mathrm{~mm}$ [5]. The data taken from the meteorological station owned by the National Meteorology and Hydrology Service (SENAMHI), a station located very close to the vineyard where this investigation was conducted, indicated that the cumulative precipitation was 32.0 $\mathrm{mm}$. Therefore, the rain was present and with it the release of ascospores, primary source of inoculum, began.

On the other hand, the temperature in Humay fluctuated between $10^{\circ} \mathrm{C}$ and $30^{\circ} \mathrm{C}$ (minimum temperature in August 2018 and maximum temperature in March 2019, respectively). This did not affect the normal development of the antagonist, according to the indications that Trichoderma spp. grow best at a temperature that ranges between $25^{\circ} \mathrm{C}$ and $30^{\circ} \mathrm{C}$ [20]. Trichoderma strains need to cover the thermal spectrum of the target organism. The optimum germination temperature of oidium conidia is $25^{\circ} \mathrm{C}$, while the mycelium develops between $21^{\circ} \mathrm{C}$ and $30^{\circ} \mathrm{C}$. Thus, under optimal conditions, the formation of new colonies takes only 5 days [36]. Moisture can also affect the availability of essential nutrients for the growth of the antagonist, therefore, the application of Trichoderma should be scheduled at periods when there will be adequate humidity to stimulate spore germination. Oidium is considered a xerophytic fungus and its conidia can germinate with only $20 \%$ relative humidity; germ tube development and infection are highly favored by a relative humidity between $40 \%$ and $100 \%$, as is sporulation. The ability of oidium to germinate in low humidity 
conditions would be explained by the high water content in conidia vacuoles, about $70 \%$ compared to $10 \%$ in other fungi [36].

The commercial strain of $T$. viride was used exclusively at an actual concentration of $4 \times 10^{7}$ conidia/g, which did not exert $100 \%$ biological control against oidium under field conditions. On the other hand, the chemical treatment applied showed an inhibitory effect by stopping the growth of the fungus in the phenological stages of inflorescence emergence, flowering, peasized berries, bunch closure and berry ripening. This is due to the fact that the district of Humay is governed by a program of exact applications (that is, in each farm they always establish a schedule of chemical fungicide applications weekly) without considering the presence of the pest in the field. The treatment with exclusive use of $T$. viride for the control of oidium in the grapevine variety Italia presented an average efficiency of $92 \%$ in the leaves and $81 \%$ in clusters. The latter resembles the results proposed by Ahmed [5]. That study was carried out in Egypt, using the mixture of three Trichoderma strains (with a concentration of $30 \times 10^{6}$ spores $/ \mathrm{ml}$ ), obtaining a high biocontrol efficiency of E. necator $(80.16 \%$ and $89.95 \%$ in two trial campaigns during 2016 and 2017, respectively) for the Thompson Seedless grapevine variety.

For future trials it is recommended to use native Trichoderma strains, taking into account first that they must be evaluated as highly effective in laboratory conditions as the main requirement for the development of a successful biocontrol system [5]. The other option suggested is to mix antagonistic fungi, which may be $T$. harzianum and $T$. viride. These formulations of mixtures of beneficial fungi can sometimes lead to an antagonistic effect, that is, decrease the effectiveness of the treatment, or give a synergistic effect and increase the effectiveness [5].

In summary, the control of grapevine infections by oidium becomes a challenge with biological options, because most farmers have become accustomed to using chemicals when the disease has already been uncontrolled. This produces critical damage in the vineyards such as the reduction of the quantity and quality of the grapes, and therefore, it is recommended to act preventively by applying a biological product on the crop.

Our results suggest that native Trichoderma strains, isolated from vineyards that have received various controls with fungicides should be used, since those microorganisms would be already adapted to different conditions and, therefore, there would have been selection of some type of resistance. For example, Guerrero and Arias [37] determined in vitro the effect of the fungicides copper oxide and azoxystrobin on the development of two Trichoderma species, concluding that although the fungus retards its growth, it continues to reproduce, thus ensuring the perpetuation of its species in these conditions and allowing its use in the field.

\section{CONCLUSION}

The treatment with exclusive use of T. viride for the control of oidium in the grapevine variety Italia presented an average efficiency of $92 \%$ in the leaves, compared to the conventional treatment based on chemicals that had an average efficiency of $96 \%$. When evaluating the clusters, it was observed that the application of $T$. viride had lower efficacy $(81 \%)$ than the application of chemical fungicides (88\%) to control oidium. These data allow us to offer an alternative in the integrated management of this phytopathogen.

The use of T. viride is considered as a clean technology contrary to the use of fungicides of chemical origin, allowing us not to have problems of pesticide residues that ensure the health of the consumer and the final distribution to the users for the benefit of the farmer.

The findings of this study indicate that both treatments were effective. To ensure better control of the oidium, good canopy management is recommended, as well as preventive applications of the T. viride fungus before pruning. This would favor that the plant develops immunity not only against Erysiphe necator, but also against other phytopathogens.

\section{ACKNOWLEDGMENTS}

The authors would like to thank the National Agricultural Innovation Program, the Technological Institute of Production, CITEagroindustrial - Ica for the allocation of the budget for the conduction of this research.

\section{REFERENCES}

1. Cáceres H, Quispe P, Pignataro D, Orjeda G, Lacombe T. Morphological characterization of grape varieties for Pisco production under conditions of the middle zone of the Ica Valley, Peru. Scientia Agropecuaria. 2017;8:63-72.

2. Lacoste L. The grapevine and wine in South America: The displacement of wine poles (XVI to XX). Universum Magazine 2 No. 2004;19:62-93.

3. Cepes PE. Notiagro. Ica has viniferes 6000 acres of grapes and Pisco (online). Perú. 2015.

4. Pertot I, Caffi T, Rossi V, Mugnai L, Hoffmann C, Grando MS, et al. A critical review of plant protection tools for reducing pesticide use on grapevine and new perspectives for the implementation of IPM in viticulture. Crop Protection. 2017;97:70-84.

5. Ahmed MFA. Evaluation of some biocontrol agents to control Thompson seedless grapevine powdery mildew disease. Egyptian Journal of Biological Pest Control. 2018;28:93.

6. Agrios GN. Fitopatología. México: Uteha (Noriega Editores). 1995.

7. Castillo D. Control biológico del oídium por acción de Trichoderma harzianum y Trichoderma sp. en plantas de vid Vitis vinifera a nivel de campo, en Pocollay - Tacna. Ciencia y Desarrollo. 2007;11:35-40.

8. Campbell P, Bendek C, Latorre B. Risk of powdery mildew (Erysiphe necator) outbreaks on grapevines in relation to cluster development. Cien Inv Agr. 2007;34:5-11.

9. World Health Organization. Pesticide residues in food? 2016.

10. Bader A, Salerno G, Covacevich F, Consolo V. Native Trichoderma harzianum strains from Argentina produce indole - 3 acetic acid 
and phosphorus solubilization, promote growth and control wilt disease on tomato (Solanum lycopersicum L.). Journal of King Saud University - Science. 2019;32:867-873.

11. Bautista E, Mesa L, Gómez M. Alternatives for the production of microbial biopesticides based on fungi: the case of Latin America and the Caribbean. Scientia Agropecuaria. 2018; 9: 585-604.

12. Ram RM, Keswani C, Bisen K, Tripathi R, Singh SP, Singh HB. Biocontrol technology: Eco-friendly approaches for sustainable agriculture. In Omics Technologies and Bio-Engineering. 2018;1:177-190.

13. Marrone PG. The market and potential for biopesticides. In A.S. Series, Biopesticides: State of the Art and Future Opportunities. American Chemical Society. 2014;1172:245-258.

14. Arthurs S, Dara SK. Microbial biopesticides for invertebrate pests and their markets in the United States. Journal of Invertebrate Pathology. 2019;165:13-21

15. Agrawal SC, Khare MN, Agrawal PS. Biological control of Sclerotium rolfsii causing collar rot of lentil [India]. Indian phytopathology. 1978;30:176-179.

16. Wells H, Bell D, Jaworski C. Efficacy of Trichoderma harzianum as a biocontrol for Sclerotium rolfsii. Phytopathology. 1972;62:442-447.

17. Mukherjee PK, Raghu K. Trichoderma sp. as a microbial suppressive agent of Sclerotium rolfsii on vegetables. World Journal of Microbiology and Biotechnology. 1997;13:497-499.

18. Tsahouridou PC, Thanassoulopoulos CC. Proliferation of Trichoderma koningii in the tomato rhizosphere and the suppression of damping-off by Sclerotium rolfsii. Soil Biology and Biochemistry. 2002;34:767-776.

19. Pérez LM. Bases Moleculares Del Control Biológico Defitopatógenos. Experiencia Chilena. Facultad de Ciencias Agronómicas, Universidad de Chile. 2005;1:1-108

20. Polanco CD, Castro JL. Estudios sobre el control biológico de Sclerotium rolfsii. Agronomía Tropical. 2005;27:539-547.

21. Khan MR, Mohiddin FA. Trichoderma: Its multifarious utility in crop improvement. In: Prasad, R., Gill, S.S., Tuteja, N. (Eds.), New and Future Developments in Microbial Biotechnology and Bioengineering: Crop Improvement through Microbial Biotechnology. Elsevier Publications, Amsterdam, The Netherlands. 2018;1-496.

22. López-Ferrer U, Brito-Vega H, López-Morales D, Salaya-Dominguez J, Gómez-Méndez E. Trichoderma role in agroforestry-cacaotal systems as an antagonal agent. Tropical and Subtropical Agroecosystems. 2017;20:91-100.

23. Chávez-García M, Montaña-Lara J, Martínez-Salgado M, MercadoReyes M, Rodríguez MY Quvedo-Hidalgo B. Efecto del sustrato y la exposición a la luz en la producción de una cepa de Trichoderma sp. Universitas Scientiarum. 2008;13:245-251.
24. Chamorro Jara EE. Evaluation of the Biocontroller Effectiveness of Bacillussubtilis and Two Native Strains Of Trichoderma Spp. Onincidence and Severity of Oidio De Vid (Uncinula necator) In: Vitis vinifera Variedad Cabernet Sauvignon. (Doctoral dissertation, Universidad de Talca (Chile). Escuela de Agronomía). 2006.

25. Gómez Ramirez H. Trichoderma viride Pers. Cepa CCB-LA103. 2014.

26. Horsfall JG, Heuberger JW. Measuring magnitude of a defoliation disease in tomatoes. Phytopathology. 1942;32:226-232.

27. Wheeler BEJ. An introduction to plant disease. Wiley, London, UK. 1969;1:301.

28. Fernández González M. Phenological and aerobiological study in a vineyard in the Ribeiro región. (Doctoral dissertation, Bioloxía vexetal e ciencias do solo). 2011.

29. Sarasola AA, Roca De Sarasola MA. Fitopatología, Editorial Hemisferio sur Buenos Aires. 1975; 374.

30. Van Der Spuy JE, Mathee FN. Overwintering of the oidium stage of Uncinula necator in the buds on the grapevine. Plant Disease. 1977:61:612-615.

31. Bulit J, Lafon R. Powdery mildew of the vine: In D. M. Spencer (Ed), Powdery mildews . New York, NY: Academic Press, USA. 1978: 525-548.

32. Pearson RC, Goheen AC. Compendium of Grape Diseases. St. Paul: APS Press. 1988.

33. Berkett L, Cromwell M. Oídio de la Vid (Powdery Mildew of Grapes). Recuperado 2 diciembre, 2019.

34. Sawant IS, Wadkar PN, Ghule SB, Rajguru YR, Salunkhe VP, Sawant SD. Enhanced biological control of powdery mildew in vineyards by integrating a strain of Trichoderma afroharzianum with sulphur. Biol Control. 2017;114:133-143.

35. Inia. Oídio de la vid (Anamorfo. Oidium tuckeri Berk. Teleomorfo. Uncinula necator (Schwein.) Burril). 2016.

36. Fuertes A. Efectividad de fungicidas biológicos en el control de oídio (Erysiphe necator Schwein). Memoria para optar el título profesional de Ingeniero Agrónomo. Facultad de Ciencias Agronómicas. Escuela de Pregrado. Universidad de Chile. 2015;1-20.

37. Guerrero R, Arias D. Evaluación del efecto de fungicidas sobre el desarrollo de dos especies de Trichoderma (Fungi: Ascomycota: Hypocreaceae) utilizadas en el biocontrol de hongos patógenos de cacao. Revista Amazónica Ciencia y Tecnología. 2012;1:11-17.

38. Aliquó G, Díaz Bruno A. Operaciones en verde manejo de canopia. 2008.

39. Grainge M, Ahmeds A. Handbook of plant with pest control properties. John Wiley and Sons, New York, USA, 1988;470. 